\title{
INVESTIGATION ON PHARMACOGNOSY OF KATHA POWDER AS WELL AS IT'S IN VITRO CYTOTOXIC ACTIVITY
}

\author{
PANKAJ SHARMA*
}

Department of Pharmacy, Institute of Pharmacy and Research, S.J.J.T University, Jhunjhunu, Rajasthan, India. Email: pankajsharmadrugs@gmail.com

Received: 12 September 2020, Revised and Accepted: 21 November 2020

\section{ABSTRACT}

Objective: The present study delves into the investigation of quantitative phytochemical in Katha powder, and it is in vitro cytotoxic activity.

Methods: Coarsely dried chips of Acacia catechu heartwood were treated with a 10\% hydro-alcoholic solution to obtain Katha as the final product. The powdered Katha was standardized through pharmacognostic parameters. Phytochemical investigations were carried out to screen polyphenols (tannins and flavonoids) of interest which later were confirmed by thin-layer chromatography. The cytotoxicity effect of Katha powder on MCF-7, A431, and HepG2 cells was characterized by the trypan blue dye exclusion and MTT colorimetric assays technique. Control assay was carried out for samples containing only the appropriate volumes of blank solutions and showed no effect on cell growth. Different cells were exposed to Katha powder for about $48 \mathrm{~h}$ and performed cytotoxicity assays. The effect of Katha powder against these cell lines concentration range $10-100 \mu \mathrm{g} / \mathrm{ml}$ showed a decrease in percent cell viability in a dose-dependent manner, as compared with that of the control when examined by the trypan blue exclusion assay technique and MTT colorimetric assays technique.

Results: Quantitative phytochemical investigations were showed that Katha is rich in the content of polyphenols (tannins and flavonoids) and having good pharmacological potential. The effect of Katha powder against these cell lines concentration range 10-100 $\mu \mathrm{g} / \mathrm{ml}$ showed a decrease in percent cell viability in a dose-dependent manner.

Conclusion: So from this investigation it is to be suggested that the Katha powder is rich in the phenolic compound and shows a good anticancer effect against MCF-7, A431, and HepG2 cells.

Keywords: Acacia catechu, MCF-7, A431, HepG2, Polyphenols, Katha.

(C) 2021 The Authors. Published by Innovare Academic Sciences Pvt Ltd. This is an open access article under the CC BY license (http://creativecommons.org/ licenses/by/4.0/) DOI: http://dx.doi.org/10.22159/ajpcr.2021v14i1.39717. Journal homepage: https://innovareacademics.in/journals/index.php/ajpcr

\section{INTRODUCTION}

The use of herbal medicines has become a global subject with medical and economic ramifications over the past few decades. Acacia catechu (L.f.) Willd. is known by the name "khadira" in Ayurveda belongs to the Leguminosae family [1]. The plant is a small moderate-sized tree about 10-13 m height extensively scattered throughout India [2]. The medicinal significance of this plant is reflected by the use of leaves, bark, and heartwood in several Ayurvedic formulations for 1000 years [3]. The heartwood of $A$. catechu has more potent medicinal activity in comparison to its leaves and bark. The heartwood extract of $A$. catechu has been reported to have various pharmacological effects such as antiinflammatory [4], antioxidant [5], antimicrobial, immunomodulatory, antipyretic, hypoglycemic, anti-diarrheal, and hepatoprotective. The plant contains polyphenols such as tannins, and flavonoids along with carbohydrates and proteins [6]. The major constituents of the plant include catechin $(-)$, epicatechin, epigallocatechin, epicatechin gallate, and epigallocatechin gallate. Other constituents include rocatechin, phloroglucin, protocatechuic acid, quercetin, poriferasterol glucosides, lupenone, lupeol, procyanidin AC, kaempferol, dihydrokaemferol, taxifolin, (+)-afzelchin gum, and minerals [7]. The heartwood of this plant is known by the name "Katha" which is well known for its diverse pharmacological properties [8]. The present study on Katha powder delves for investigation of quantitative phytochemical in Katha, and its in vitro evaluation of cytotoxic activity.

\section{METHODS}

\section{Plant material}

The heartwood of the plant was collected in November 2019 from Solan district of Himachal Pradesh, India, which further was authenticated by Raw material herbarium and museum, NISCAIR, New Delhi, India. A voucher specimen of the plant was preserved in the herbarium for reference (NISCAIR/RHHD/Consult/2019/3465-66).

\section{Preparation of Katha}

The heartwood of $A$. catechu was dried at room temperature $\left(25 \pm 2^{\circ} \mathrm{C}\right)$ for 4 consecutive weeks and pulverized [9]. Katha was obtained from the heartwood of $A$. catechu by boiling the chips of heartwood with a $10 \%$ hydro-alcoholic solution. The steps involved in Katha processing are to be described in Fig. 1.

\section{Standardization of Katha}

The specimen was processed for pharmacognostic standardization through morphological studies, powder microscopy, percentage yield of Katha after extraction, fluorescence analysis, and loss on drying. The presence of active compounds was confirmed with the help of thin-layer chromatography (TLC) using desired mobile and stationary phases.

\section{Quantitative phytochemical screening}

Quantitative phytochemical screenings of Katha powder were performed as per standard protocols to detect the number of total phenols, total flavonoids, and total tannin content [10].

\section{Determination of total phenolic content}

Folin-Ciocalteu reagent was used to evaluate the total phenolic content of the extract using Gallic acid as standard [11]. The standard curve of Gallic acid was prepared by taking 500, 250, 125, 62.5, 31.25, and $15.625 \mu \mathrm{g} / \mathrm{ml}$ concentrations [12]. The procedure for determining the absorption of various concentrations is the same as follows for Katha powder. All the samples were subjected to a temperature of $60^{\circ} \mathrm{C}$ on 


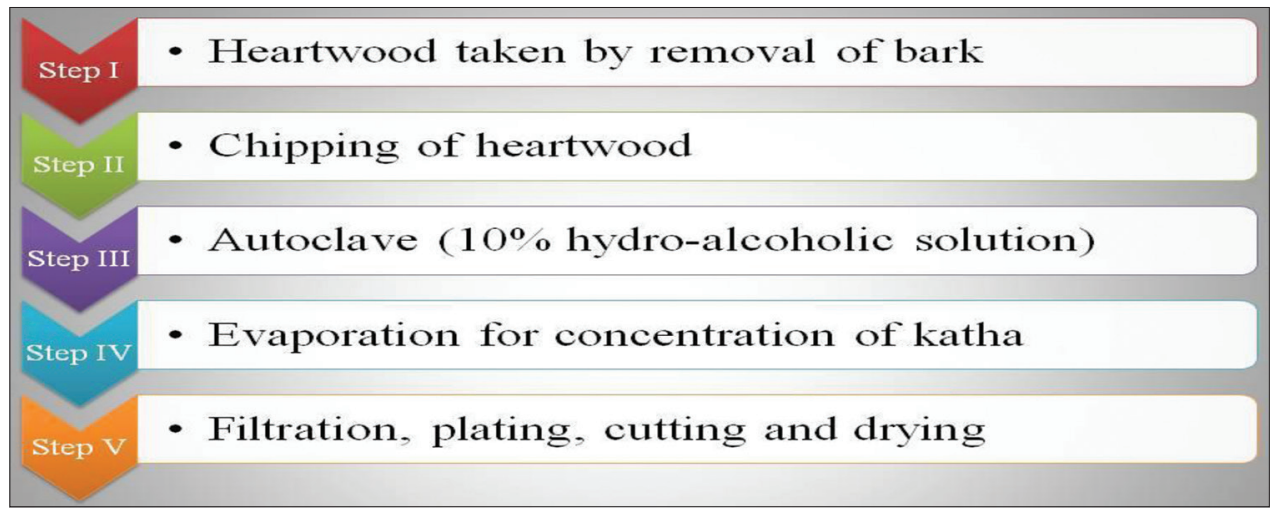

Fig. 1: Preparation of Katha

a water bath for $1 \mathrm{~h}$, followed by cooling to room temperature. $400 \mu \mathrm{L}$ of this solution was transferred into the test tube containing $1.6 \mathrm{~mL}$ of sodium carbonate $(7.5 \%$ in deionized water) and $2 \mathrm{~mL}$ of FolinCiocalteu reagent $(0.1 \%$ in deionized water). Further, all the samples were incubated for $1 \mathrm{~h}$ at room temperature. Absorbance was measured at $525 \mathrm{~nm}$ using UV-Spectrophotometer. All the readings were taken in triplicate. Total phenolic content was expressed in mg Gallic acid equivalent (GAE) per gram of Katha powder, using calibration curve [13].

\section{Estimation of flavonoid content}

The most commonly used method to determine total flavonoid contents by taking quercetin as standard [14]. Different concentrations of Katha powder and standard were prepared as above and 100, 50, 25, and $12.5 \mu \mathrm{g} / \mathrm{ml}$ Katha powder, and the standard was added to the test tube containing $75 \mu \mathrm{L}$ of $5 \%$ NaNO2 solution [15]. The mixture was allowed to stand for $10 \mathrm{~min} .150 \mu \mathrm{L}$ of a $10 \% \mathrm{AlCl} 3.6 \mathrm{H} 20$ solution were then added to every sample and were allowed to stand for $5 \mathrm{~min}$. Further $0.5 \mathrm{~mL}$ $\mathrm{NaOH}(1 \mathrm{M})$ and $2.5 \mathrm{~mL}$ of distilled water were added to each sample. Absorbance was measured at $510 \mathrm{~nm}$ using UV-Spectrophotometer. All the observations were taken in triplicate. Total flavonoid content was calculated as milligram quercetin equivalent $(\mathrm{QE}) / \mathrm{g}$ using the linear regression equation obtained for quercetin [16].

\section{Detection of tannin content}

The total tannin content was determined following the International Standard method with slight alteration using tannic acid as standard [17]. Sample concentrations were taken at $2 \mathrm{mg} / \mathrm{mL}$ for each of the Katha powder. Initially, $200 \mu \mathrm{L}$ of the sample were mixed with freshly prepared $200 \mu \mathrm{L}$ of $0.35 \%$ ferric ammonium citrate, followed by $200 \mu \mathrm{L}$ of $0.8 \%$ ammonia solution [18]. Finally, volume was made up to $4 \mathrm{~mL}$ by adding $3.4 \mathrm{~mL}$ of water. The absorbance of the mixture was measured at $525 \mathrm{~nm}$. The results were expressed as milligram tannic acid equivalent (TAE)/g dry Katha powder [19].

\section{In vitro cell lines study of Katha powder}

MCF-7, A431, and HepG2 were obtained from the National Center for Cell Science, Pune, and maintained in DMEM supplemented with $10 \%$ FBS (Fetal Bovine Serum), $100 \mu \mathrm{g} / \mathrm{ml}$ streptomycin, and $100 \mathrm{IU} / \mathrm{ml}$ penicillin [20]. The cell was inoculated at $37^{\circ} \mathrm{C}$ in an atmosphere of $5 \% \mathrm{CO}_{2}$. Human lymphocytes were isolated from peripheral blood as described by cell where suspended in complete RPMI 1640 medium supplemented with $10 \%$ FBS, $5 \mathrm{~g} / \mathrm{ml}$ phytohemagglutinin, and maintained at $37^{\circ} \mathrm{C}$ in a $5 \% \mathrm{CO}_{2}$ humidified incubator [21]. Stock solutions of extract /compound were prepared in dimethyl sulfoxide (DMSO) and solutions of different concentrations were obtained by diluting with culture medium. The final concentration of DMSO was less than $0.4 \%$ in all experiments. For 96 well plates, cells were seeded at approximately $7.5 \times 10^{3}-1.5 \times 10^{4}$ cells per well, and for 24 well plates and seeding density were approximately $1.5 \times 10^{4}-5 \times 10^{4}$ cells per well depending on the doubling time of individual cell lines [22].

\section{Technique used for cell line assay}

For the assay study, the two techniques are to be namely used is trypan blue dye exclusion assay and MTT assay technique [23]. The dye exclusion test is used to determine the number of viable cells present in a cell suspension. It is based on the principle that lives cells possess intact cell membranes that exclude certain dyes, such as trypan blue, Eosin, or propidium, whereas dead cells do not trypan blue that is oxidized by living cells to a colorless product and dead cells remain blue colored [24]. Cells were seeded in a 24-well plate and then treated with various concentrations of test samples. The plate was incubated at $37^{\circ} \mathrm{C}$ and the number of culture cells in the different wells was counted using a hemocytometer after staining with $0.4 \%$ trypan blue after $48 \mathrm{~h}$ to calculate the percentage viability [25]. Cells were examined and counted under a light microscope at 10 x (Olympus, Japan) [26].

$\%$ Cell viability $=\frac{\text { Number of viable cells }(\text { unstained cells })}{\text { Total number of cells }(\text { stained and unstained) }} \times 100$

MTT assay is based on the metabolic reduction of MTT by the mitochondrial succinate dehydrogenase of intact cells to purple formazan product. MTT is a mono tetrazolium salt, the reduction of which is one of the most frequently used methods for measuring cell proliferation and cytotoxicity [27]. Cells were incubated in 96-well microtiter plates for $48 \mathrm{~h}$. Following the addition of the test samples, the plates were incubated for an additional $48 \mathrm{~h}$. Controlled well contained medium alone. Three triplicate wells were used in each point in the experiments after $48 \mathrm{~h}$ of incubation at $37^{\circ} \mathrm{C}, 50 \mu \mathrm{l}$ MTT solution (5 $\mathrm{mg} / \mathrm{ml}$ in phosphate-buffered saline) was added, and incubated for another $4 \mathrm{~h}$ at $37^{\circ} \mathrm{C}$ in a $5 \% \mathrm{CO}_{2}$ incubator. The resulting MTT - Formazan product was dissolved by $100 \mu \mathrm{l}$ of isopropanol and the plates were gently shaken to solubilize the formed formazan. The amount of formazan was determined by measuring the absorbance (OD) at $570 \mathrm{~nm}$ using a Bio-Rad 550 enzymes-linked immunosorbent assay microplate reader [28].

$\%$ Cell viability $=\frac{\text { Number of viable cells (unstained cells) }}{\text { Total number of cells (stained and unstained) }} \times 100$

\section{Morphological changes of cells}

The analysis of cell morphological changes was evaluated for $48 \mathrm{~h}$ in the absence or presence of test samples in 24-well plates. At the end of the incubation period, cells were observed under phase contrast inverted microscopes at $\times 200[29]$.

\section{Hoechst assay}

Differential staining with specific fluorochromes can be used to distinguished cells undergoing apoptosis from viable and necrotic cells. The analysis of cell morphology was evaluated Hoechst fluorescence staining [30]. The cells were cultured in 24-well plates to $85 \%$ confluence and then treated with the test sample for $48 \mathrm{~h}$, 
as described previously. Next, the cell was washed in PBS and fixed with $4 \%$ formaldehyde in PBS for $15 \mathrm{~min}$ and stained with $10 \mu \mathrm{g} / \mathrm{ml}$ Hoechst 33258 (HO; Sigma, St. Louis, MO, USA) at room temperature for $10 \mathrm{~min}$ in PBS. The apoptosis was classified by morphology and color of the cells and qualified. Finally, after the cells were washed with PBS, morphological changes were observed under the fluorescence microscopes [31]

\section{Acridine orange/ethidium bromide (AO/EB) fluorescences staining}

The analysis of changes in cell morphology was evaluated using AO/EB fluorescence staining [32]. Briefly, to a suspension of test sample-treated cells were added $4 \mu \mathrm{l} / \mathrm{ml}$ of dye mixture, containing $100 \mu \mathrm{g} / \mathrm{ml}$ acridine orange (Sigma, USA), and $100 \mu \mathrm{g} / \mathrm{ml}$ ethidium visualized immediately under fluorescence microscopes [33]

\section{RESULTS}

\section{Pharmacognostic data}

Katha occurs in pieces of variable sizes of $4-4.5 \mathrm{~cm}$ in length and 3.5-4.5 cm in-breath, yellowish-brown in color, the fracture is hard, characteristic odor with an astringent taste. Powder microscopy of Katha revealed the presence of acicular type crystals, fibers, and pitted vessels, as shown in Fig. 2. Total ash and acid insoluble ash value was found to be $11.5 \% \mathrm{w} / \mathrm{w}, 0.68 \% \mathrm{w} / \mathrm{w}$ which confirms the presence of inorganic content in the drug. The moisture content of the drug was found to be between 9 and $13 \%$ w/w. On exposure to UV light, Katha showed dark brown fluorescence.

\section{Percentage yield of Katha after extraction}

The data about Katha content from the heartwood of A. catechu are presented in Table 1 showing with maximum Katha content of $14.64 \%$ w/w was obtained and minimum Katha content is $7.95 \%$ w/w, respectively.

\section{Phytochemical studies}

Preliminary phytochemical screening of Katha showed the presence of tannins, flavonoids, saponins, and triterpenes, as shown in Table 2, but the main allure of screening was the presence of polyphenols (tannins and flavonoids) in ethyl acetate extract. The melting point of the extract was found to be between 150 and $210^{\circ} \mathrm{C}$ and in UV light extract showed magenta color fluorescence.

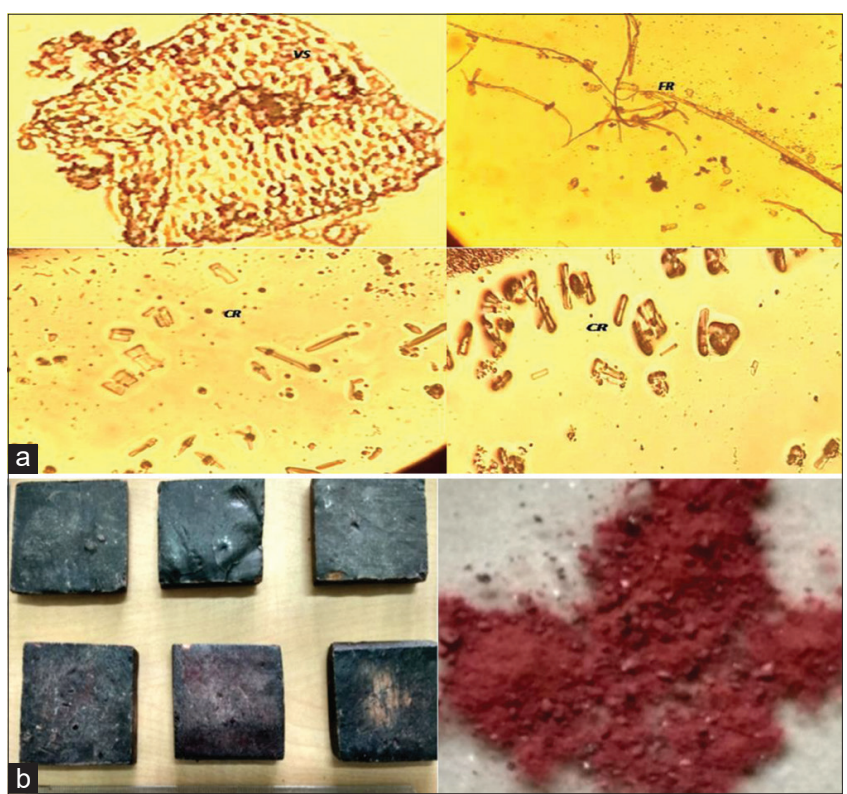

Fig. 2: (a) Microscopic characteristics of Katha. (b). Description of Katha and its powder. VS: Vessels, CR: Crystals, FR: Fibers
TLC profile

TLC of Katha powder on pre-coated TLC plates Merck GF-254 using chloroform:methanol:water (8:2:0.5) as mobile phase showed three different spots at Rf $0.2,0.4$, and 0.5 after detection with vanillin sulfuric acid reagent and in UV-366 nm, as shown in Fig. 3 which were later identified as epicatechin/catechin, epigallocatechin, and quercetin, respectively.

\section{Quantitative phytochemical screening}

The standard curve of Gallic acid obtained at different concentration $(\mu \mathrm{g} / \mathrm{ml}) 500,250,125,62.5,31.25$, and 15.625 , respectively. The total phenolic content of the Katha powder was calculated in terms of mg GAE per gram of Katha powder. Total phenolic contents were calculated using linear regression equation $y=0.003 X+0.033$ at $R^{2}=0.998$. Total phenolic content in Katha powder was calculated to be $96.4 \mathrm{mg}$ GAE/ Gram of Katha powder, respectively. In another side estimation of total flavonoids content, the standard curve of quercetin was plotted at different concentrations $(\mu \mathrm{g} / \mathrm{ml}) 100,50,25,12.5$, and 6.75, respectively. Linear regression was applied to the obtained curve. Total flavonoid content was then calculated from equation $\mathrm{y}=0.009 \mathrm{x}-0.014$ at $\mathrm{R}^{2}=0.999$ in terms of mg QE/g of Katha powder. Total flavonoid content in Katha powder was calculated to be $46.43 \mathrm{mg}$ QE/g of Katha powder. The standard curve of tannic acid obtained at different concentration $(\mu \mathrm{g} / \mathrm{ml}) 500,250,125,62.5,31.25$, and 15.625 , respectively. The total tannin content of the extract fractions was calculated in terms of mg GAE per gram of Katha powder. Total tannin contents were calculated using linear regression equation $=0.016 x+0.004 R^{2}=0.999$. The total tannin content in Katha powder was calculated to be tannins $96.4 \mathrm{mg} \mathrm{TAE} / \mathrm{g}$ dry extract of extract fractions, respectively. It is to be represented in Fig. 4.

In vitro cytotoxicity testing of Katha powder

In vitro proliferation study

The cytotoxicity effect of Katha powder on MCF-7, A431, and HepG2 cells was characterized by the trypan blue dye exclusion method and colorimetric assays using MTT. Control assay was carried out for samples containing only the appropriate volumes of blank solutions and showed no effect on cell growth. Different cells were exposed to Katha powder for about $48 \mathrm{~h}$ and cytotoxicity assays. The percentage cell viability of different Katha extracts on MCF-7, A431, and HepG2 cells was evaluated by the trypan blue dye exclusion method. The

Table 1: The percent yield of Katha

\begin{tabular}{llll}
\hline Trial & Katha extract & \% yield w/w & Average value w/w \\
\hline Trial I & $\begin{array}{l}\text { 10\% hydro-alcoholic } \\
\text { hot distilled water }\end{array}$ & $9.12 \%$ & $11.87 \%$ \\
Trial II & $\begin{array}{l}10 \% \text { hydro-alcoholic } \\
\text { hot distilled water }\end{array}$ & $11.95 \%$ & \\
Trial III & $\begin{array}{l}10 \% \text { hydro-alcoholic } \\
\text { hot distilled water }\end{array}$ & $14.54 \%$ & \\
\hline
\end{tabular}

Table 2: Preliminary phytochemical screening of Katha powder

\begin{tabular}{lllll}
\hline S. No. & Metabolite & Test & Katha powder & Inference \\
\hline 1. & Tannins & Gelatin & +++ & Present \\
2. & Flavonoids & $\begin{array}{l}\text { Lead acetate, } \\
\text { Alkaline reagent }\end{array}$ & + & Present \\
3. & Triterpenes & $\begin{array}{l}\text { Liebermann- } \\
\text { Burchard }\end{array}$ & + & Present \\
& Glycosides & $\begin{array}{l}\text { Modified } \\
\text { borntrager's }\end{array}$ & + & Present \\
4. & Saponins & $\begin{array}{l}\text { Froth formation } \\
\text { Salkowski }\end{array}$ & ++ & Present \\
5. & Steroids & $\begin{array}{l}\text { Salkent } \\
\text { Mayers and }\end{array}$ & - & $\begin{array}{l}\text { Absent } \\
\text { 7. }\end{array}$ \\
Alkaloids & $\begin{array}{l}\text { Magner reagent } \\
\text { Wabent }\end{array}$ & \\
\hline
\end{tabular}

+++ Active constituent is highly present, ++ Active constituent is moderately present, + Active constituent is slightly present, - Active constituent absent 


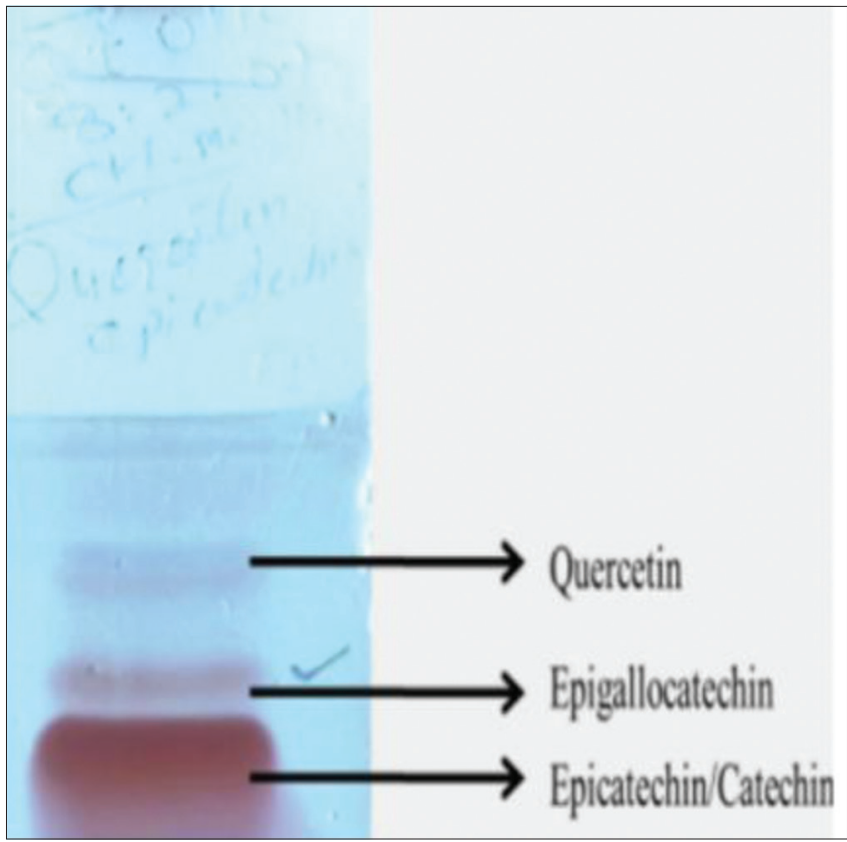

Fig. 3: TLC analysis of Katha powder results of the trypan blue assay are presented in Table 4, respectively. The effect of Katha powder against these cell lines concentration range $10-100 \mu \mathrm{g} / \mathrm{ml}$ showed a decrease in percent cell viability in a dose-dependent manner, as compared with that of the control when examined by the trypan blue exclusion assay (Fig. 5).

It was found that the percentage growth inhibition increased with increasing concentrations of Katha powder, steadily in the case of the Katha powder against MCF-7, A431, and HepG2 cells. Katha powder showed a good linearity range against MCF-7, A431, and HepG2 cells. Overall, the Katha powder shows the greatest activity against these cell lines.

Effect of Katha powder on human peripheral lymphocytes

The cytotoxic effect of Katha powder on human peripheral lymphocytes was characterized by MTT assay. When the different concentrations of Katha powder (10-100 $\mu \mathrm{g} / \mathrm{ml})$ were added to normal lymphocytes, the Katha powder did not show any toxic effect on lymphocytes. The cell number and cell survival both increased, as the concentration of the Katha powder increased (Fig. 6).

Effect of Katha powder on the morphology of the cells

To investigate the effect of Katha powder on the morphology of the apoptotic cells, Hoechst 33258 (HO) and AO/EB staining were used. Cells stained with $\mathrm{HO}$ after treatment with different concentrations

Standard curve of Gallic acid

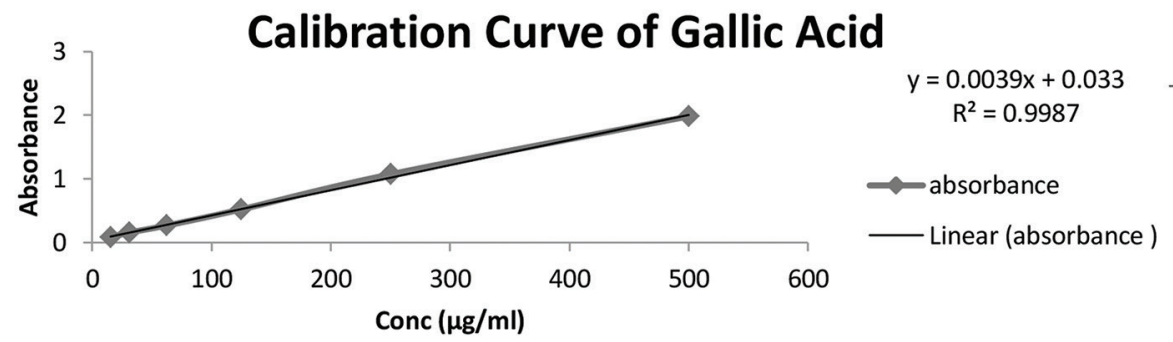

Standard curve of quercetin

\section{Calibration Curve of Qurecetin}

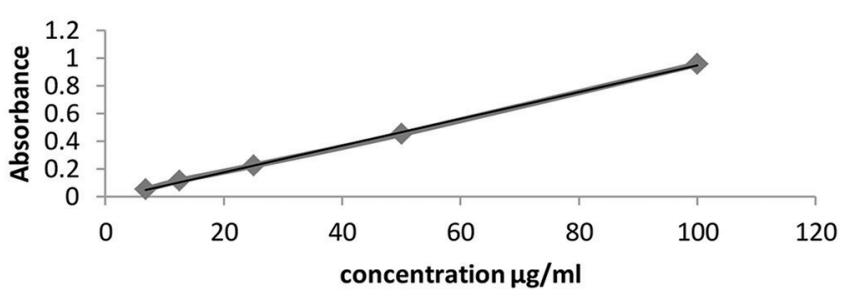

$y=0.0096 x-0.0144$ $R^{2}=0.9993$

-absorbance

_Linear (absorbance)

Standard curve of tannic acid

\section{Calibration curve of Tannic acid}

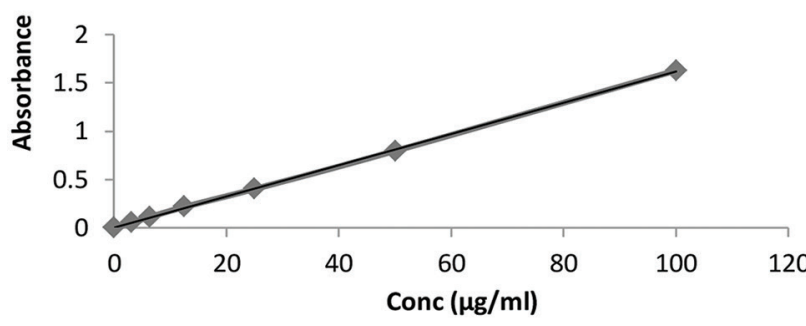

$y=0.0162 x+0.0043$ $R^{2}=0.9997$

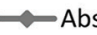

- Linear (Abs)

Fig. 4: Standard calibration curve of Gallic acid, quercetin, and tannic acid 


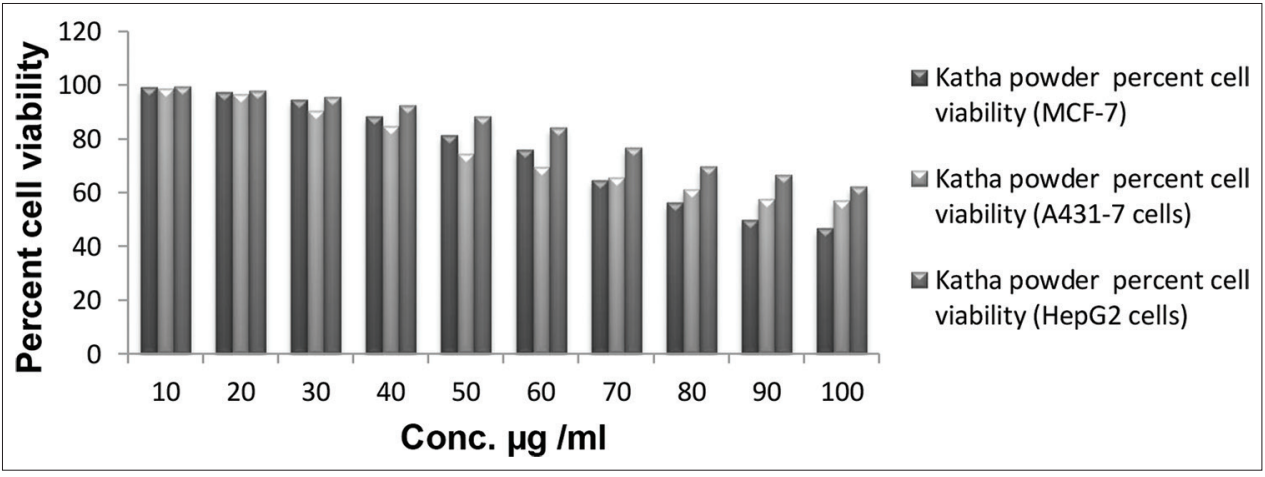

Fig. 5: Percent cells viability of Katha powder (MCF-7, A431-7, and HepG2 cells) using trypan blue exclusion assay

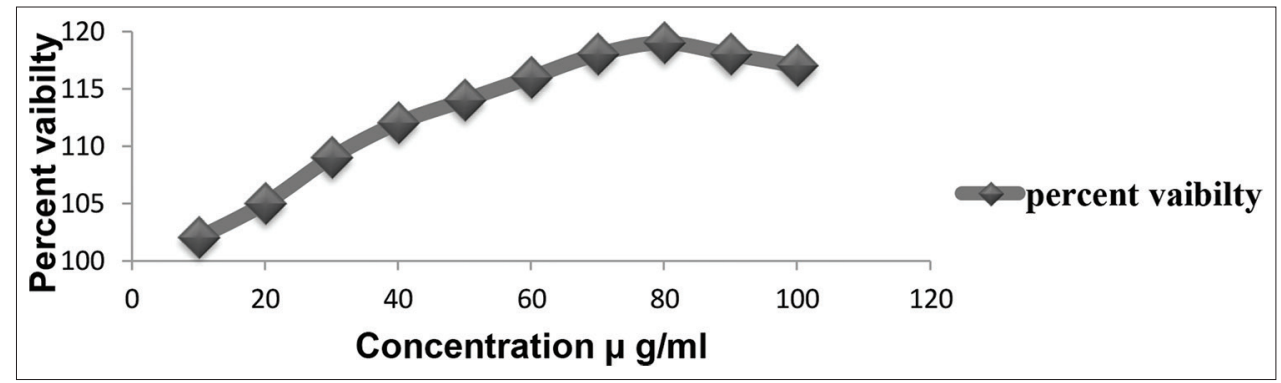

Fig. 6: Effect of Katha powder on the percentage viability of normal lymphocytes as measured by MTT assay

Table 3: Effect of Katha powder on percent cell viability (MCF-7, A431, and HepG2 cells) using trypan blue exclusion assay

\begin{tabular}{lll}
\hline Concentration $(\mu \mathrm{g} / \mathrm{ml})$ & $\begin{array}{l}\text { Katha powder percent cell } \\
\text { viability (MCF-7) }\end{array}$ & $\begin{array}{l}\text { Katha powder percent cell } \\
\text { viability (A431-7 cells) }\end{array}$ \\
\hline 10 & 99.12 & $\begin{array}{l}\text { Katha powder percent cell } \\
\text { viability (HepG2 cells) }\end{array}$ \\
20 & 97.42 & 98.73 \\
30 & 94.57 & 96.56 \\
40 & 88.45 & 89.56 \\
50 & 81.37 & 74.43 \\
60 & 75.89 & 69.56 \\
70 & 64.67 & 65.72 \\
80 & 56.25 & 61.17 \\
90 & 49.78 & 57.68 \\
100 & 46.92 & 57.21 \\
\hline
\end{tabular}

Table 4: Effect of Katha powder on human peripheral lymphocytes

\begin{tabular}{llllll}
\hline S. No. $\begin{array}{l}\text { Concentration } \\
\text { in } \boldsymbol{\mu g} / \mathbf{m l}\end{array}$ & \multicolumn{3}{l}{ Percent viability } \\
\cline { 3 - 6 } & & Trial 1 & Trial 2 & Trial 3 & $\begin{array}{l}\text { Average trial } \\
\text { value }\end{array}$ \\
\hline 1. & 10 & 102 & 102 & 102 & 102 \\
2. & 20 & 105 & 105 & 105 & 105 \\
3. & 30 & 109 & 109 & 109 & 109 \\
4. & 40 & 112 & 112 & 112 & 112 \\
5. & 50 & 114 & 114 & 114 & 114 \\
6. & 60 & 116 & 116 & 116 & 116 \\
7. & 70 & 118 & 118 & 118 & 118 \\
8. & 80 & 119 & 119 & 119 & 119 \\
9. & 90 & 118 & 118 & 118 & 118 \\
10. & 10 & 117 & 117 & 117 & 117 \\
\hline
\end{tabular}

(50 and $100 \mu \mathrm{g} / \mathrm{ml}$ ) of Katha powder for $48 \mathrm{~h}$ showed marked morphological changes indicative of cell apoptosis were observed, including chromatin condensation and fragmentation in MCF-7 Fig. 7a-f, A431 (Fig. 8a-f), and HepG2 cells (Fig. 9a-f).
As shown in Fig. 7a-f, MCF-7 cells treated with Katha powder exhibited characteristics changes of the apoptosis, for example, cell shrinkage, nuclear condensation, and fragmentation and formation of apoptotic bodies. Cells treated with $50 \mu \mathrm{g} / \mathrm{ml}$ of Katha powder showed the sign of every apoptosis (Fig. 7c and d).

A431 cells treated with Katha powder show characteristics changes of apoptosis, for example, cell shrinkage, nuclear condensation and fragmentation, and formation of apoptotic bodies (Fig. 8).

Cells treated with 50 and $100 \mu \mathrm{g} / \mathrm{ml}$ of Katha powder showed similar features of apoptosis, that is, early apoptosis and chromatin condensation (Fig. 8c and d). It is shown in Fig. 8e and f, the apoptosis nuclei clearly and highly condensed chromatin that was uniformly fluorescent.

The nucleus was shown as bright green and the cell profiles were dark green which suggested that the treatment of HepG2 cells with the Katha powder induce apoptosis. Cells treated with $50 \mu \mathrm{g} / \mathrm{ml}$ of Katha power shown the sign of early apoptosis (Fig. 9c and d) and, on the other hand, cells treated with $100 \mu \mathrm{g} / \mathrm{ml}$ of the Katha powder similar features of late apoptotic activity with apoptotic bodies formation (Fig. 9e and f). 


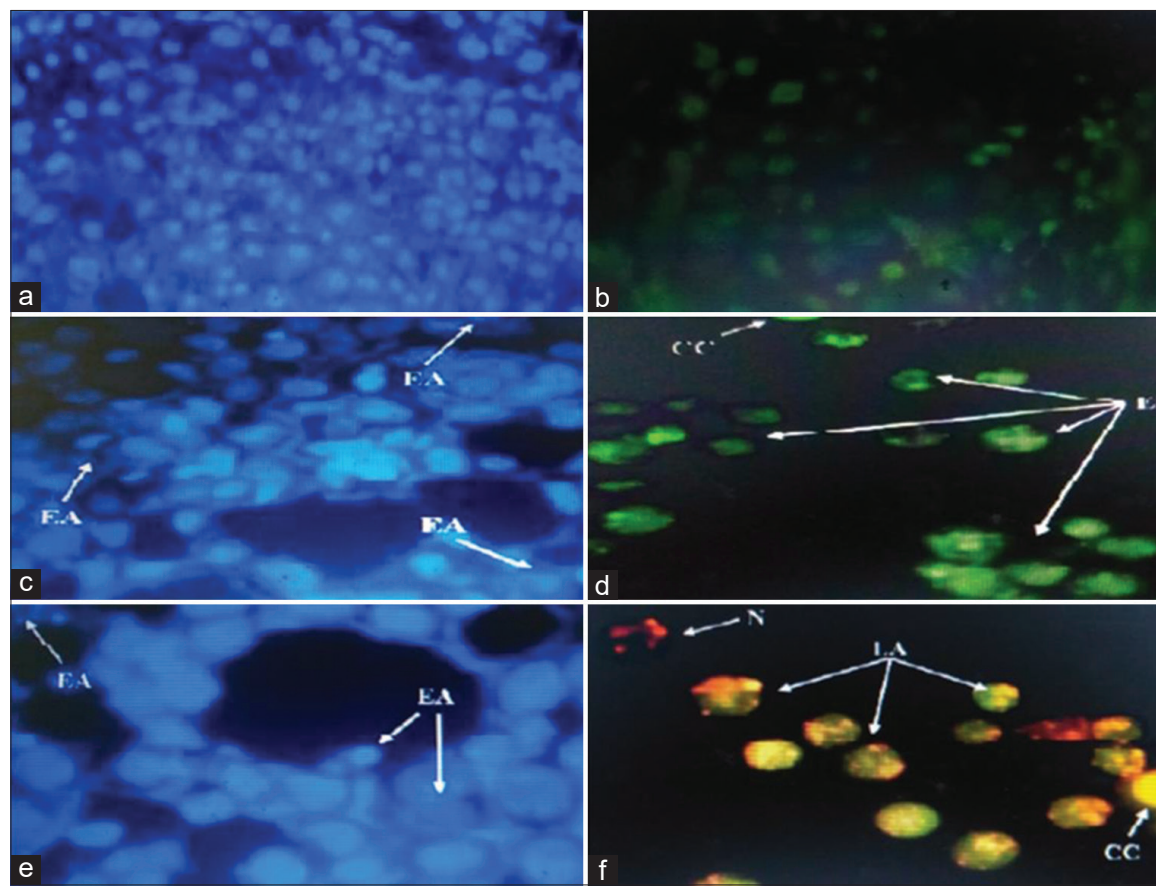

Fig. 7: (a-f) apoptosis assay by Hoechst and acridine orange/ ethidium bromide (MCF-7 cells). (a and b) MCF-7 control cells, (c and d) MCF7 cells treated with $50 \mu \mathrm{g} / \mathrm{ml}$ of Katha powder. (e and f) MCF-7 cells treated with $100 \mu \mathrm{g} / \mathrm{ml}$ of Katha powder. Early apoptosis (EA) cells with apoptotic nuclei stained by Hoechst with fluorescence in blue spectrum (arrow); chromatin condensation (CC); late apoptosis (LA); necrosis (N) stained acridine orange and ethidium bromide (AO/EB) shown fluorescence in green and yellow/orange spectrum (arrow). On the other hand, cells treated with $100 \mu \mathrm{g} / \mathrm{ml}$ of Katha powder showed a similar feature but with extra features of late apoptotic activity with the formation of the apoptotic bodies (Fig. 7e and f)

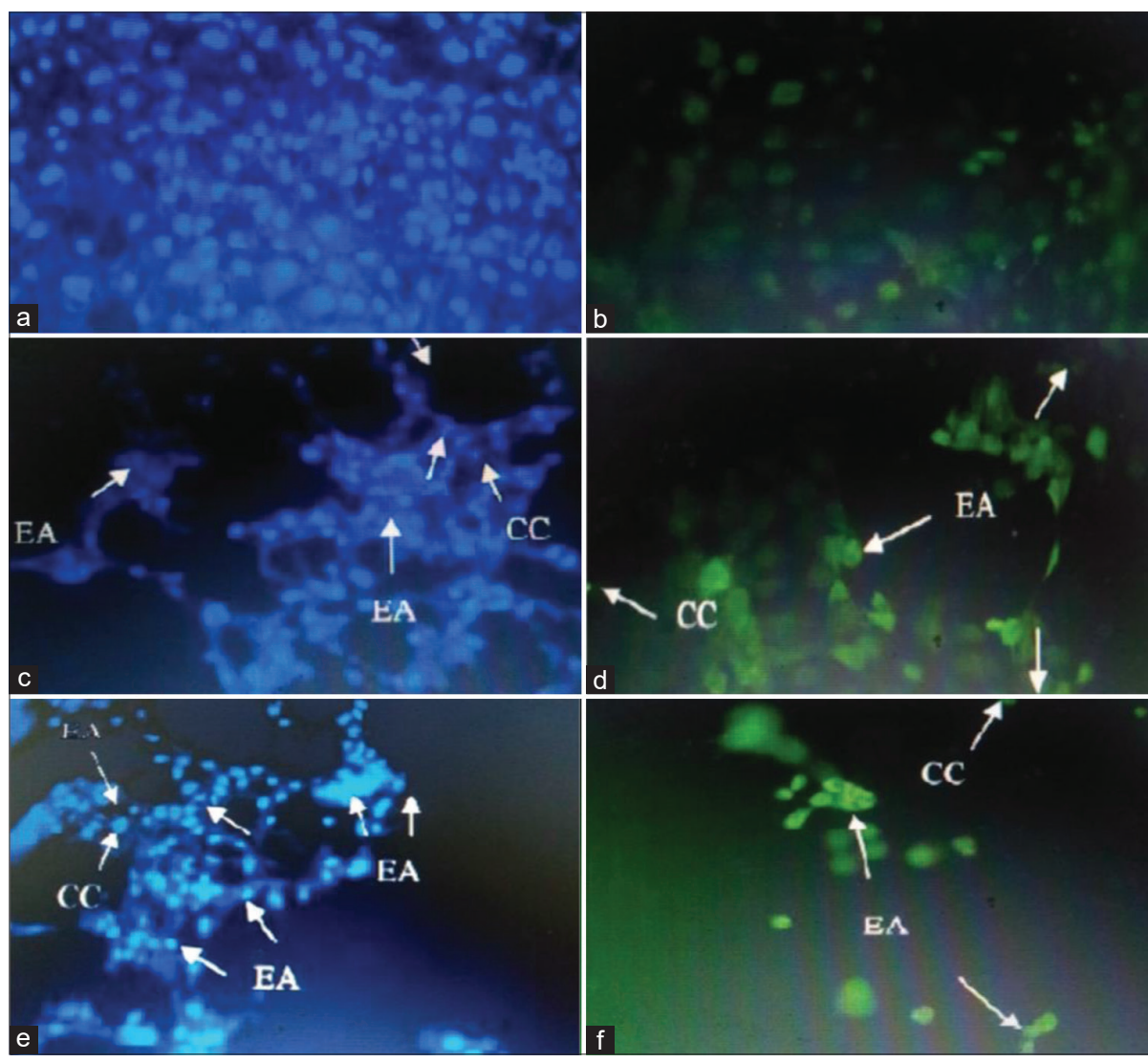

Fig. 8: (a-f) Apoptosis assay by Hoechst and acridine orange/ethidium (AO/EB) bromide (A431 cells). (a and b) A431 control cells (c and d) A431 cells treated with $50 \mu \mathrm{g} / \mathrm{ml}$ of Katha powder (e and f) A431 cells treated with $100 \mu \mathrm{g} / \mathrm{ml}$ of Katha powder. Early apoptosis (EA); chromatin condensation (CC) cells with apoptotic nuclei stained by Hoechst with fluorescence in blue spectrum (arrow) and cells stained with AO/EB shown fluorescence in the green spectrum (arrow) 

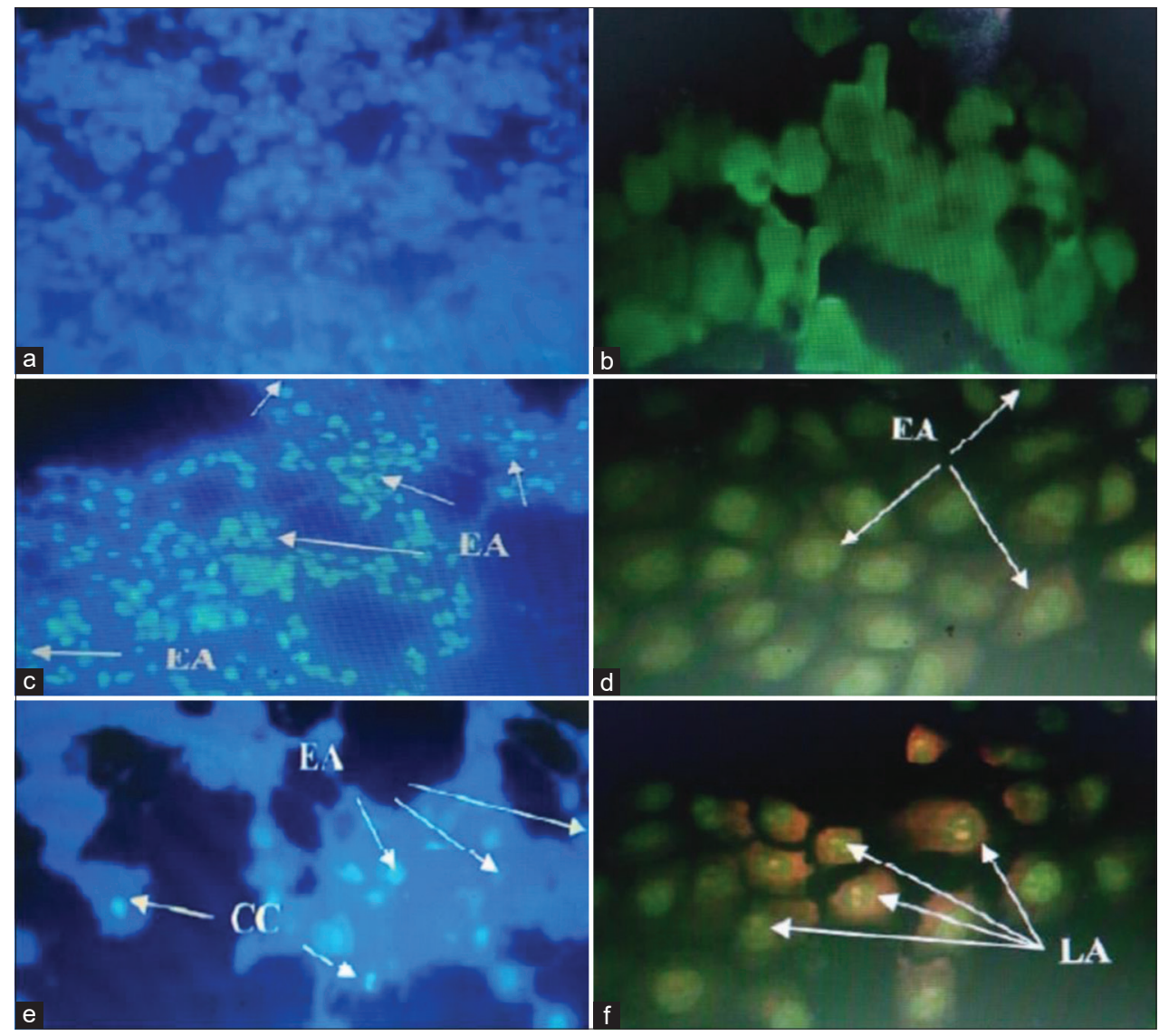

Fig. 9: (a-f) Apoptosis assay by Hoechst and acridine orange/ethidium bromide (HepG2 cells). (a and b) HepG2 control cells. (c and d) HepG2 cells treated with $50 \mu \mathrm{g} / \mathrm{ml}$ of Katha powder (e and f) HepG2 cells treated with $100 \mu \mathrm{g} / \mathrm{ml}$ of the Katha powder. Early-stage apoptosis (EA); chromatin condensation (CC) cells with apoptotic nuclei stained by Hoechst with fluorescence in blue spectrum (arrow); late apoptosis (LA) stained acridine orange and ethidium bromide (AO/EB) shown fluorescence in green and orange spectrum (arrow).

\section{DISCUSSION}

Katha obtained by boiling the heartwood of $A$. catechu with a $10 \%$ hydro-alcoholic solution increased the percentage yield value by $10 \% \mathrm{w} / \mathrm{w}$. In chromatographic studies, four active substances were identified based on their respective Rf values it shows the presence of catechin/epicatechin, epigallocatechin, and quercetin, etc., the cytotoxic effect of the Katha powder on MCF-7, A431, and HepG2 cells was characterized by trypan blue dye exclusion method and MTT colorimetric assay. Overall, the Katha powder showed the greatest activity against these cancer cell lines and was used to carry further study on human peripheral lymphocytes. For this study, the human peripheral lymphocytes were isolated and the effect of Katha powder on the percent viability of normal lymphocytes was calculated. The result showed the Katha powder did not show any toxic effect to lymphocytes which concluded that the Katha powder has no toxicity to normal cells. So as for as morphological alteration concerned the MCF-7, A431, and HepG2 cell following the treatment with Katha powder indicative of cell apoptosis. Besides, marked morphological changes that occurred in the apoptotic cell were also perceived through Hoechst 33258 (HO) and AO/EB staining, and this help in deducing that the cell death observed was not due to necrosis, but due to apoptosis. It was possible to observe a better difference between early and late apoptosis, showing that the Katha powder exhibited a longer concentration-response effect for late apoptosis and a smaller concentration effect for early apoptosis, in both of the studied concentration.

\section{CONCLUSION}

Katha powder was found rich in the polyphenolic compound, tannin, and flavonoid content. These active compounds potentiate the market value of Katha powder for therapy. Further, if we concern with in vitro proliferation of Katha powder against these cell lines concentration range $10-100 \mu \mathrm{g} / \mathrm{ml}$ showed a decrease in percent cell viability in a dose-dependent manner, as compared with that of the control when examined by the trypan blue exclusion assay. Overall, the Katha powder showed the greatest activity against these cancer cell lines and was used to carry further study on human peripheral lymphocytes. For this study, the human peripheral lymphocytes were isolated and the effect of Katha powder on the percent viability of normal lymphocytes was calculated. The result showed that the Katha powder did not show any toxic effect to lymphocytes which concluded that the Katha powder has no toxicity to normal cells.

\section{ACKNOWLEDGMENTS}

The authors extend thanks to Dr. Vineet Mehta and Mr. Vikrant Arya Assistant Professor Government College of Pharmacy Rohru for his technical support to carry out this research study.

\section{AUTHOR FUNDING}

Not applicable.

\section{CONFLICT OF INTEREST}

The authors declare that they have no conflict of interest, financial, or otherwise.

\section{REFERENCES}

1. Sharma P. Investigation on photodecomposition of standardised ethyl acetate fraction of Katha. Pharmacogn J 2020;12:815-20. 
2. Chauhan NS. Medicinal and Aromatic Plants of Himachal Pradesh. New Delhi: Indus Publishing; 1999.

3. Meena AK, Bansal P, Kumar S. Plants-herbal wealth as a potential source of ayurvedic drugs. Asian J Tradit Med 2009;4:152-70.

4. Azab A, Nassar A, Azab AN. Anti-inflammatory activity of natural products. Molecules 2016;21:1321.

5. Zahin $\mathrm{M}$, Aqil $\mathrm{F}$, Ahmad I. The in vitro antioxidant activity and total phenolic content of four Indian medicinal plants. Int J Pharm Pharm Sci 2009;1:88-95.

6. Thakur AV, Ambwani S, Ambwani TK. Preliminary phytochemical screening and GC-MS analysis of leaf extract of Acacia catechu (Lf) Willd. Int J Herb Med 2018;6:81-5.

7. Hazra B, Sarkar R, Ghate NB, Chaudhuri D, Mandal N. Study of the protective effects of Katha (heartwood extract of Acacia catechu) in liver damage induced by iron overload. J Environ Pathol Toxicol Oncol 2013;32:229-40.

8. Lakshmi T, Geetha RV, Anitha R. Acacia catechu willd: A pharmacological review. Int J Curr Res Rev 2011;3:101-11.

9. Wang L, Shen X, Mi L, Jing J, Gai S, Liu, et al. Simultaneous determinations of four major bioactive components in Acacia catechu (Lf) Willd and Scutellaria baicalensis Georgi extracts by LC-MS/MS: Application to its herb-herb interactions based on pharmacokinetic, tissue distribution and excretion studies in rats. Phytomedicine 2019;56:64-73.

10. Srinivasan N. Pharmacognostical and phytochemical evaluation of Cassia alata Linn. J Med Plants 2018;6:69-77.

11. Maurya S, Singh D. Quantitative analysis of total phenolic content in Adhatoda vasica Nees extracts. Int J PharmTech Res 2010;2:2403-6.

12. Muthukumarasamy R, Ilyana A, Fithriyaani NA, Najihah NA, Asyiqin N, Sekar M. Formulation and evaluation of natural antioxidant cream comprising methanolic peel extract of Dimocarpus longan. Int J Pharm Clin Res 2016;8:1305-9.

13. Ghate NB, Chaudhuri D, Mandal N. In vitro assessment of Tinospora cordifolia stem for its antioxidant, free radical scavenging, and DNA protective potentials. Int J Pharm Bio Sci 2013;4:373-88.

14. Kalita P, Tapan BK, Pal TK, Kalita R. Estimation of total flavonoids content (TFC) and antioxidant activities of methanolic whole plant extract of Biophytum sensitivum Linn. J Drug Deliv Ther 2013;3:33-7.

15. Hazra B, Biswas S, Mandal N. Antioxidant and free radical scavenging activity of Spondias pinnata. BMC Complement Alternat Med 2008;8:1-10.

16. Prakash NK, Ranjith M, Sripriya N, Lakshmi RP, Deepa S, Bhuvaneswari S. Antioxidant, free radical scavenging activity and GC-MS studies on Pedilanthus tithymaloides (1.) Poit. Int J Pharm Pharm Sci 2014;6:284-87.

17. John B, Sulaiman CT, George S, Reddy VR. Total phenolics and flavonoids in selected medicinal plants from Kerala. Int J Pharm Pharm Sci 2014;6:406-8

18. Bhattacharya E, Dutta R, Chakraborty S, Biswas SM. Phytochemical profiling of Artocarpus lakoocha Roxb. Leaf methanol extract and its antioxidant, antimicrobial, and anti-oxidative activities. Asian Pac J
Trop Biomed 2019;9:484-92

19. Brownell LA, Chu M, Hong MF, Eu-Jin HY, Jia Q, Ping JI, et al. Compositions and Methods for Managing or Improving Bone Disorders, Cartilage Disorders, or Both. United States: The United States Patent Application US 15/663,793; 2018.

20. Khonkarn R, Okonogi S, Ampasavate C, Anuchapreeda S. Investigation of fruit peel extract as sources for compounds with antioxidant and antiproliferative activities against human cell lines. Food Chem Toxicol 2010;48:2122-9.

21. Chen IS, Quan SG, Golde DW. Human T-cell leukemia virus Type II transforms normal human lymphocytes. Proc Natl Acad Sci 1983;80:7006-9.

22. Dekosky BJ, Ippolito GC, Deschner RP, Lavinder JJ, Wine Y, Rawlings M, et al. High-throughput sequencing of the paired human immunoglobulin heavy and light chain repertoire. Nat Biotechnol 2013;31:166-9.

23. Choudhari MK, Haghniaz R, Rajwade JM, Paknikar KM. Anticancer activity of Indian stingless bee propolis: An in vitro study. Evid Based Complement Alternat Med 2013;2013:1-10.

24. Strober W. Trypan blue exclusion test of cell viability. Curr Protoc Immunol 1997:21:3B

25. Sutradhar BC, Park J, Hong G, Choi SH, Kim G. Effects of trypsinization on the viability of equine chondrocytes in cell culture. Pak Vet J 2010;30:232-8

26. Tokunaga M, Kitamura K, Saito K, Iwane AH, Yanagida T. Singlemolecule imaging of fluorophores and enzymatic reactions achieved by objective-type total internal reflection fluorescence microscopy. Biochem Biophys Res Commun 1997;235:47-53.

27. Kroll A, Pillukat MH, Hahn D, Schnekenburger J. Current in vitro methods in nanoparticle risk assessment: Limitations and challenges. Eur J Pharm Biopharm 2009;72:370-7

28. Monga J, Pandit S, Chauhan CS, Sharma M. Cytotoxicity and apoptosis induction in human breast adenocarcinoma MCF-7 cells by (+)-cyanidan-3-ol. Exp Toxicol Pathol 2013;65:1091-100.

29. Murphy M, Drago J, Bartlett PF. The fibroblast growth factor stimulates the proliferation and differentiation of neural precursor cells in vitro. J Neurosci Res 1990;25:463-75.

30. Mpoke SS, Wolfe J. Differential staining of apoptotic nuclei in living cells: Application to macronuclear elimination in Tetrahymena. J Histochem Cytochem 1997;45:675-83.

31. Allen RT, Hunter WJ, Agrawal DK. Morphological and biochemical characterization and analysis of apoptosis. J Pharmacol Toxicol Methods 1997;37:215-28.

32. Panchal PK, Meena SK, Singh K, Sharma N. Anticancer and antimicrobial potential of barleria prionitis leaves ethanol extract. Int J Pharm Pharm Sci 2018;10:100-3

33. Sharma M, Agrawal SK, Sharma PR, Chadha BS, Khosla MK, Saxena AK. Cytotoxic and apoptotic activity of essential oil from Ocimum viride towards Colo 205 cells. Food Chem Toxicol 2010;48:336-44. 